\title{
GERAKAN ORGANISASI BERBASIS KEAGAMAAN MELAWAN HIV/AIDS DI INDONESIA: PENILAIAN PADA WILAYAH JAWA TENGAH DAN BALI
}

\author{
Anna Marie Wattie \\ Departemen Antropologi Universitas Gadjah Mada, Yogyakarta, Indonesia \\ Nono S. A. Sumampouw \\ Fakultas Ilmu Sosial dan Politik Universitas Sam Ratulangi \\ nono_yoi@yahoo.co.id
}

\begin{abstract}
This article aims to understand the approach used by Faith Based Organization (FBO) in the tackling and handling program of HIV and AIDS, in relation to the prevention, infection, as well as the treatment in social-cultural perspective. The data collecting is done through profound interview and observation in two research areas: North-Beach Areas (Pantai Utara), Central Java and Denpasar, Bali. Both locus were chosen and compared based on the differences in sociocultural formation, particularly in the religious background majority which in control of the social life. It is found that the involvement of both the institution and religious leaders in the countermeasures of HIV and AIDS has a strategical value either directly or indirectly. The involvement of religious organizations in these two areas, even though differ in effectiveness, scale of implementation, problems encountered, value approach, intervention and organizational attachment, and the social-cultural construction of the society has adduced changes in discourse and practices related to the HIV and AIDS issues, either in the circle of the religious leaders and the community in general. The North-Beach area in Central Java which only for the past five years go through with the countermeasures program of HIV and AIDS formally, structurally, direct, and organizational by FBO in this case Nahdlatul Ulama (NU), has the effectivity and acceptance for different people and slower that what has happened in Bali, where the FBO tends to be involved through non-organizational network.
\end{abstract}

Keywords: HIV, AIDS, ODHA, Religion, Moslem, Hindu-Bali, FBO, NU, Banjar

\begin{abstract}
Abstrak. Artikel ini bertujuan memahami pendekatan yang dilakukan Lembaga Berbasis Keagamaan atau Faith Based Organization (FBO) dalam program penanggulangan dan penanganan HIV dan AIDS, baik terkait dengan pencegahan, penularan maupun perawatan dalam perspektif sosial-budaya. Pengumpulan data dilakukan lewat wawancara mendalam dan observasi di dua wilayah penelitian, yaitu: daerah Pantai Utara, Jawa Tengah dan Denpasar, Bali. Kedua lokus dipilih dan dibandingkan dengan alasan memiliki formasi sosio-kultural berbeda terutama dalam latar belakang agama mayoritas penduduk yang mengatur kehidupan bermasyarakat. Ditemukan bahwa pelibatan lembaga dan tokoh keagamaan dalam penanggulangan HIV dan AIDS punya nilai strategis, baik secara langsung maupun tidak langsung. Pelibatan organisasi keagamaan di dua daerah ini, sekalipun berbeda dalam hal efektifitas, skala pelaksanaan, masalah yang dihadapi, pendekatan nilai, intervensi dan keterikatan organisasional serta konstruksi sosial-budaya masyarakat telah menunjukkan adanya perubahan wacana dan praktek terkait dengan isu HIV dan AIDS, baik di kalangan pemuka agama dan masyarakat luas. Daerah Pantai Utara Jawa Tengah yang kurang-lebih baru saja lima tahun melaksanakan program penanganan HIV dan AIDS secara formal, struktural, langsung dan organisasional oleh FBO dalam hal ini Nahdlatul Ulama (NU), memiliki efektifitas dan penerimaan di kalangan masyarakat yang berbeda serta lebih lambat daripada yang terjadi di Bali, dimana FBO cenderung dilibatkan lewat jejarang non-organisasional.
\end{abstract}

Kata Kunci: HIV, AIDS, ODHA, Agama, Islam, Hindu-Bali, FBO, NU, Banjar 


\section{Pendahuluan}

Sejak laporan awal mengenai kemunculannya pertama kali pada 1980an di Amerika Serikat, HIV/AIDS telah menyebar dan ditemukan di berbagai wilayah dunia. Sebagai salah satu epidemi yang dianggap paling berbahaya dan mematikan, berbagai riset, program dan kebijakan telah dilaksanakan untuk mengetahui pola persebaran penyakit, hubungannya dengan perilaku masyarakat dalam tujuan mencari obat atau metode penyembuhan, penanggulangan serta pencegahan paling efektif. Hal-hal tersebut tidak hanya terbatas pada persoalan medis murni semata, tetapi terutama menyangkut aspek-aspek sosial, kultural, ekonomi dan politik. Dengan kata lain, epidemi ini terutama dilihat dalam kerangka relasi antar aktor yang terlibat, termasuk dengan berbagai metode dan media yang digunakan. Hal ini tentu saja terhubung dengan berbagai macam konteks sosio-kultural secara luas yang melatar-belakangi suatu masyarakat dimana HIV/AIDS ditemukan baik dalam tingkat akar rumput hingga dalam struktur yang lebih kompleks ataupun tinggi.

Bagi Indonesia, persoalan HIV/AIDS sendiri telah lama mendapat perhatian khusus oleh pemerintah dengan berbagai program dan kerjasama yang melibatkan berbagai pihak dengan perspektif beragam, tidak semata perspektif medis. Hal tersebut dilakukan mengingat tingginya kuantitas penduduk dan kualitasnya akan HIV/AIDS yang masih rentan. Indonesia dikenal sebagai sebuah negara dengan prevalensi HIV dan AIDS yang paling cepat meningkat. ${ }^{1}$ Sekalipun angka kematian karena HIV/AIDS menurun 2\%, namun penambahan

1 Ford, K., Voluntary, HIV Testing, Disclosure Among Injections Drug Users in Bali, (AIDS; Education and Prevention, Vol. 16, No. 6, 2004), h. 487-498. infeksi baru masih tingga antara 20.00025.000 penderita per tahun. ${ }^{2}$ Hal ini berarti ancaman HIV dan AIDS masih serius dan memerlukan perhatian serta tindakan berkesinambungan.

Berbagai upaya telah dilakukan untuk mengatasinya, dari sisi pemerintah diawali dengan penguatan regulasi sejak lebih dari dua dekade yang lalu, kemudian ditandai dengan pembentukan Komisi Penanggulangan HIV/AIDS (KPA) di tiap provinsi sejak tahun 2006. Selain itu, adanya dukungan dari lembaga donor telah membuat kelompok civil society, baik LSM lokal dan internasional, organisasi sosial dan keagamaan menaruh perhatian pada isu ini dengan berbagai kekayaan metode dan variasi. Kelompok-kelompok ini juga, baik didukung oleh lembaga donor, bekerja-sama dengan pemerintah maupun bergerak secara mandiri, telah berpengaruh besar terhadap upaya penanggulangannya. Berbagai riset, survey, evaluasi dan pengembangan juga dilaksanakan untuk menilai serta meningkatkan efektifitas serta variasi usaha penanganan HIV/AIDS.

Hal tersebut telah menimbulkan suatu kesadaran akan aksi-reaksi terhadap HIV/AIDS di Indonesia yang pada dasarnya beragam dan mengikuti heterogenitas komposisi serta pengetahuan penduduk. Ini menuntut pendekatan penanggulangan tidak harus selalu dari sudut padang medis, tetapi juga sosial dan budaya. Karena menyadari pentingnya hal ini, dimana agama dan tokohnya merupakan unsur penting yang mempengaruhi masyarakat, maka sejak awal pemerintah telah melibatkan Kementerian Agama untuk mengintegrasikan isu HIV dan AIDS

2

https://www.ugm.ac.id/berita/10789.angkainf eksi.baru.hivaids.di.indonesia.capai.25.ribu.per.t ahun, diakses 31 Agustus, Pukul 1.28 WITA. 
dalam kurikulum sekolah (Stevens, 1994).

Penjelasan di atas dapat dimaknai sebagai adanya adaptasi penerimaan (institusi) keagamaan terhadap keberadaan orang dengan HIV dan AIDS (ODHA) yang seringkali merupakan kelompok marjinal dalam struktur masyarakat. Dalam berbagai kasus, nilai-nilai dan norma-norma keagamaan serta sosial budaya berdampak penting dalam strategi penanganan HIV/AIDS. Dengan demikian, sangat relevan untuk secara kontinyu mengetahui perkembangan relasi antara sudut pandang agama di mata masyarakat serta organisasi keagamaan dalam menanggulangi HIV dan AIDS di Indonesia.

Namun begitu, selain Papua, HIV/AIDS di Indonesia cenderung digambarkan (hanya) sebagai epidemi di negara berpenduduk Islam dan mengabaikan struktur populasi umat beragama yang lain dan bagaimana warga umum serta berbagai kelompok civil society seperti LSM dan lembaga keagamaan meresponsnya. Karena itu, artikel ini bermaksud melihat dan membandingkan isu ini dalam dua wilayah dengan karakteristik sosialbudaya yang berbeda, yaitu Pantai Utara Provinsi Jawa Tengah dan Bali. Kedua wilayah terkenal dengan aktivitas pariwisata dan mobilitas manusia yang berperilaku beresiko tertular HIV/AIDS. Bali dikenal sebagai kantong umat Hindu Indonesia, dimana wilayah Pantai Utara merupakan kantong umat Islam, yang mana kami bermaksud untuk melihat apakah perbedaan agama juga memberikan karakteristik khusus, unik dan tingkat efektifitas tertentu dalam menangani isu HIV/AIDS. Dengan latar pertimbangan tersebut, pertanyaan utama dalam penelitian ini ialah bagaimana institusi keagamaan, warga serta para tokoh agama Islam dan Hindu di Indonesia merespons bahaya HIV dan AIDS?.

Pertanyaan inti di atas mendorong beberapa pertanyaan spesifik yang bisa membantu melihat berbagai persoalan dalam artikel ini, yaitu: (1) Bagaimana respon warga, institusi keagamaan dan tokoh agama Islam serta Hindu terhadap HIV dan AIDS?; (2) Bagaimana institusi keagamaan Islam di Pantura terlibat dalam program penanggulangan HIV dan AIDS?; (3) Bagaimana institusi keagamaan Hindu di Bali terlibat dalam program penanggulangan HIV dan AIDS?.

Sementara itu, artikel ini bertujuan untuk memahami pendekatan yang dilakukan oleh institusi keagamaan, didalamnya tokoh dan masyarakat terkait penanganan isu HIV dan AIDS dalam perspektif sosial budaya. Melalui kajian di dua wilayah, hasil penelitian diharapkan memberi penjelasan dan pemahaman memadai tentang perspektif dan peran institusi keagamaan serta tokoh agama Islam dan Hindu dalam program penanggulangan HIV dan AIDS. Termasuk menjelaskan beragam aspek terkait dengan perspektif kelembagaan maupun individual, identifikasi program dan kegiatan, pendanaan, jejaring, hambatan, dukungan dan pencapaian.

\section{HIV AIDS dan Institusi Keagamaan}

Sejak awal kemunculan kasusnya, perkembangan program penanganan HIV dan AIDS sudah berjalan hampir tiga dekade, para ahli sepakat tentang kompleksitas permasalahan HIV dan AIDS terlebih bahwa ini bukan persoalan biomedis semata, tapi menyangkut juga persoalan sosial. Bahkan, ketika masyarakat mempunyai pengetahuan memadai tentang HIV dan AIDS, masih ada beragam aspek sosial budaya yang akan menentukan perilaku. Hal ini seragam 
dengan asumsi dasar Antropologi Kesehatan mengenai hubungan antara Kebudayaan, Perilaku dan Kesehatan dalam kaitan untuk merancang program penanganan, yaitu: before asking a group to assume new health habits, it is wise to ascertain the existing habits, how this habits are linked to one another, what functions they perform and what they mean to those who practice them. ${ }^{3}$ Sehingga, mempelajari fenomena ini dalam masyarakat, penting untuk mengerti pandangan sosial-budaya mereka terhadap HIV/AIDS atau hal-hal yang terkait dengannya.

Selain itu ada juga pendapat bahwa penanggulangan HIV dan AIDS dengan basis promosi kesehatan tidak dapat berhenti pada usaha menyebarkan informasi yang benar tentang virus dan penyakit ini sendiri. ${ }^{4}$ Asumsi dasar promosi kesehatan bahwa dengan pengetahuan yang cukup, seseorang dengan mudah dan otomatis mengubah perilakunya seringkali memperoleh halangan. Pendekatan promosi kesehatan terpusat pada individu, seseorang memanfaatkan pilihan rasionalnya berdasarkan pengetahuan tentang kesehatan yang ia dapatkan. Padahal, secara empirik dan didasarkan pada studi-studi lanjutan, persepsi soal apa yang menguntungkan bagi kesehatan dan yang merugikan (faktor risiko) tidak terbentuk sematamata oleh proses kognitif individu, tapi dipengaruhi pula oleh faktor lain dari lingkungan sosial, budaya, ekonomi dan politik di mana individu hidup. ${ }^{5}$ Hasil

${ }^{3}$ Hyder, Adnan Ali and Richard Morrow, Culture, Behavior and Health, in Michael Merson, et. al. (Eds.), International Public Health: Diseases, Programs, Systems and Policies, (Sudbury: Jones and Bartlet Publishers, 2006), h. 41-66.

4 Rhodes, Tim and Alan Quirk, Heroin, Risk and Sexual Safety: Some problems for interventions encouraging community change". In Tim Rhodes and and Richard Hartnoll (eds). AIDS, drugs and prevention: perspectives on studi juga menunjukkan bahwa petugas medis dalam hal ini perawat juga tidak secara otomatis mempraktekkan kemampuan kognisinya dan mengurangi stigma ketika harus berhadapan dengan pasien HIV dan AIDS. ${ }^{6}$

Karena adanya kesadaran akan persoalan ini, timbul pendekatan promosi kesehatan berbasis komunitas, contohnya mensyaratkan penggunaan kondom di lokalisasi. Tetapi, muncul pula argumen bahwa kedua pendekatan tersebut akan dihadapkan lagi pada pola relasi struktural yang ada di atasnya, misalnya terkait kebijakan kesehatan, regulasi, bahkan kesediaan institusi keagamaan menerima program promosi kesehatan yang diusulkan.

Pelibatan institusi keagamaan, termasuk memanfaatkan dalil-dalil agama untuk menanggulangi epidemi HIV dan AIDS menjadi penting, karena pada dasarnya mayoritas penduduk dunia terhubung dengan institusi keagamaan serta ajarannya dalam arti struktural, komunal dan bahkan psikokultural. Ini dapat terlihat bahwa HIV dan AIDS cenderung dikaitkan dengan keyakinan bahwa penyakit tersebut adalah kutukan Tuhan terhadap sekelompok orang yang berperilaku melanggar ajaran agama. Secara religius, institusi keagamaan sering mengaitkan penyebutan "kelompok berisiko" pada kategori WPS (Wanita Pekerja Seks), LBT (Lelaki Berisiko Tinggi), Penasun (pengguna Narkoba suntik), Waria, dan LSL (Lelaki Seks dengan Lelaki) yang

individual and community action, (London dan New York: Routledge, 1996), h.161-185.

5 Nasir. dan Rosenthal, The Social Context of Initiation Into Injecting Drugs In The Slums of Makassar, (International Journal of Drug Policy, Vol. 20, 2009), h. 237-243.

6 Agung Waluyo; Gabriel J. Culbert; Judith Levy RN; Kathleen F. Norr, Understanding HIV-Related Stigma Among Indonesian Nurses, (Journal of The Association Of Nurses In Aids Care, 2014), h. 1-12. 
menjadi sasaran utama program pencegahan HIV dan AIDS.

Hal di atas menjadi perhatian penting dalam melihat relasi antara stigma HIV/AIDS di masyarakat dan terutama dari sudut pandang institusi keagamaan, yang telah berpengaruh secara luas dan mendalam bagi kelompok-kelompok masyarakat tertentu yang dianggap rentan dengan penyakit ini. Kondisi ini mendorong usaha untuk merubah sasaran program dari "kelompok berisiko" ke "perilaku berisiko". Lewat penggeseran istilah dan sasaran tersebut, stigma HIV/AIDS sebagai kutukan Tuhan yang digaungkan sejak tahun 1980-an.7 Diharapkan dapat tereduksi. Menimbang kondisi masyarakat yang sangat terikat dengan nilai-nilai agama, maka peran (institusi) agama menjadi makin penting dalam implementasi program pencegahan HIV dan AIDS secara khusus, serta program penanggulangan HIV dan AIDS secara umum.

Penjelasan-penjelasan

sebelumnya memberi indikasi bahwa hubungan wacana dan praktik keagamaan dengan program penanggulangan HIV dan AIDS bukan hal baru dalam literatur akademik dan empiris di berbagai belahan dunia. Kelly dalam studi tentang gereja Katolik di Papua New Guinea menulis bahwa institusi gereja sangat besar berperan dalam penanggulangan HIV dan AIDS. Berbagai penelitian dan laporan kegiatan menunjukkan hubungan erat antara lembaga keagamaan dan perkembangan program penanggulangan HIV dan AIDS, khususnya di negara-negara Afrika.

7 Kelly A., The Body of Christ has AIDS: The Catholic Church Responding Faithfully to HIV and AIDS in Papua New Guinea, (Journal of Religion and Health, No. 48, 2009), h. 16-28.

8 Ruth Prince, Denis Philippe and Rijk van Dijk, Introduction", in Engaging Christianities: Negotiating HIV/AIDS, Health and
Berdasarkan studi yang dilakukan di beberapa negara Afrika bagian timur dan selatan, besarnya perkembangan pemahaman dan peran beragam organisasi gereja dalam kurun waktu 10 tahun, timbul perkiraan bahwa sekitar $30-70 \%$ infrastruktur kesehatan di Afrika dimiliki oleh organisasi berbasis agama. $^{8}$ Tahun 2007, WHO mempublikasikan hasil riset di Zambia dan Lesotho mengenai peran penting organisasi berbasis agama dan agen kesehatan publik dalam upaya pencegahan dan penanganan kasus HIV dan AIDS. Dalam riset ini, sekitar $40 \%$ jasa dan fasilitas perawatan di Lesotho hampir sepertiga dijalankan oleh organisasi berbasis agama, rumah sakit serta pusat kesehatan Kristen.

Relasi institusi agama dengan HIV dan AIDS juga terlihat di Senegal yang sekitar 95\% penduduknya adalah Muslim. Pihak-pihak berwenang di bidang keagamaan, bersama bergerak memperjuangkan penanggulangan AIDS. Workshop dan penyuluhan diadakan serta melibatkan pihak-pihak dari berbagai agama untuk mendiskusikan masalah HIV dan AIDS. Dalam kampanye yang mereka lakukan, memang kebanyakan dari mereka tidak secara eksplisit menganjurkan penggunaan kondom. Kebanyakan lebih menekankan pada aspek kesetiaan dan abstinensi. Selain itu, banyak dari organisasi berbasis agama ini mengadakan program konseling dan tes HIV dan AIDS bagi warga sekitar sebagai upaya penanganan serta dukungan (mental) terhadap mereka yang akan melakukan tes, keluarga penderita, bahkan penderita itu sendiri. ${ }^{9}$

Social Relations in East and Southern Africa, (Africa Today, Special Issue, Vol. 56, N0.1, 2009), h. v-xviii.

${ }^{9}$ Feirus Surur dan Kaba Mirgissa, "The Role of Religious Leaders in HIV/AIDS Prevention, Control, and Patient Care and Support: A Pilot 
Sejalan dengan itu, esensi nilainilai agama yang diyakini warga juga berperan penting. Studi di Etiopia yang melibatkan tokoh Muslim dan Kristen Ortodoks menunjukkan bahwa dengan pelatihan memadai, para tokoh agama merupakan mitra penting dalam usaha penanggulangan HIV dan AIDS terutama terkait dengan penyadaran, perubahan perilaku dan penghapusan stigma bagi ODHA. Perbandingan yang dilakukan di tiga negara berpenduduk mayoritas Muslim: Bangladesh; Indonesia; dan Iran menemukan ada asosiasi antara afiliasi keagamaan Islam dengan prevalensi HIV dan AIDS sehingga afiliasi keagamaan harus diperhitungkan sebagai faktor penting dalam penurunan HIV dan AIDS. ${ }^{10}$

Selain hubungan struktural dengan pendekatan organisasional semacam itu, relasi asosiatif stigma HIV, AIDS dengan agama juga nampak dalam kasus Asia Tenggara, secara khusus di Malaysia misalnya. Menggambarkan persebaran HIV yang dibaca secara sosial sebagai akibat dari hubungan sexual campur antar bangsa dan ras yang berbeda latar belakang kultural, agama namun bekerja di wilayah industri Malaysia, dimana salah satunya adalah para pekerja Indonesia, pendekatan dan penjelasan-penjelasan dengan nilai-nilai keagamaanlah yang sering digunakan untuk menghadapi fenomena HIV dan AIDS, hal mana langsung dihubungkan dengan persoalan moral sebagai narasi besar.

Project in Jimma Zone", (in Northeast African Studies, Vol. 7, No. 2, 2000), h. 59-79.

10 Monshipouri, Mahmood and Travis Trapp, HIV/AIDS, Religion, and Human Rights: $A$ Comparative Analysis of Bangladesh, Indonesia, and Iran, (Human Rights Review No. 13, 2012), h. 187-204.

11 Crisovan, P. 'Risky' Business: Cultural Conception of HIV/AIDS in Indonesia. PhD Dissertation. (Graduate Faculty of the Department of Anthropology, School of Arts and Sciences, University of Pittsburgh, 2006).
Kasus Indonesia juga tidak jauh berbeda. Jogjakarta sebagai wilayah berpenduduk mayoritas muslim, konsep kultural masyarakat menganggap bahwa HIV/AIDS adalah persoalan moralitas dan penyakit kutukan sebagai akibat dari rendahnya praktek penderita terhadap nilai-nilai keagamaan. ${ }^{11}$ Bahkan dalam diskursus umum umat Islam yang dijadikan Fatwa oleh MUI (Majelis Ulama Indonesia), warga muslim yang hidup dengan HIV dan AIDS dijadikan kategori tersendiri dan akhirnya mereproduksi kategori kelas sosial baru serta meruncingkan diskriminasi ${ }^{12}$

Begitu juga halnya yang terjadi di daerah Papua, sebuah wilayah di Indonesia dengan penduduk mayoritas Kristen, dimana secara umum penderita HIV dan AIDS mendapat diskriminasi karena dianggap sebagai sebuah penyakit moral. Namun begitu, organisasi berbasis keyakinan (FBO Faith Based Organization-) adalah salah satu ujung tombak dalam memerangi persoalan ini lewat pendampingan dan edukasi, yaitu Yayasan Kesehatan Bethesda. ${ }^{13}$

Pengalaman-pengalaman yang disajikan dalam berbagai studi di atas, pada dasarnya memberi penjelasan bahwa dalam tingkatan global, nasional, regional hingga lokal, institusi keagamaan memiliki relasi signifikan dengan berbagai upaya penanggulangan atau bahkan pembentukan diskursus mengenai HIV dan AIDS dalam berbagai

12 Ahmad Syams Madyan, "The Reproduction of Discourse, The Exercise of Power and Creation of Piety In The Issue of HIV an AIDS and Islam in Indonesia”, (Religio: Jurnal Studi Agama-agama, Vol. 3, No. 2, September, 2013), h. 131-154.

13 Bani Cheema, Combating HIV/AIDS in Marginalized Communities: Papua and West Papua Provincies, Master Thesis, University of San Fransisco, 2014. 
tingkatan, termasuk di Indonesia baik sejak tingkat nasional hingga lokal. Secara khusus, dalam kasus HIV dan AIDS Indonesia, yang paling sering mendapat tempat untuk dikomparasikan secara akademik adalah wilayah-wilayah dengan latar belakang penduduk mayoritas beragama Islam dan Kristen. Sementara, komparasi antara wilayah berpenduduk mayoritas Muslim dengan mayoritas beragama Hindu kurang mendapat perhatian akademis, dimana artikel ini bermaksud mengambil tempat tersebut.

\section{HIV dan AIDS di Indonesia: Kehadiran dan Partisipasi Organisasi Berbasis Keagamaan}

Kasus AIDS pertama di Indonesia ditemukan tahun 1987 dan baru pertengahan tahun 1990-an ada peningkatan tajam penularan di kalangan pengguna narkoba dan zat adiktif lewat jarum suntik (Penasun) ${ }^{14}$. Selama lebih dari 10 tahun setelah itu, perkembangan kasus HIV dan AIDS meningkat tajam, tidak hanya di kalangan yang dianggap berperlaku berisiko tinggi, tapi juga warga yang sebelumnya tidak diperhitungkan menjadi pengidap, yaitu ibu rumah tangga, bayi dan anak-anak.

Respons pemerintah terhadap kondisi ini ditandai dengan pembentukan Komisi Penanggulangan AIDS Nasional (KPAN) pada tahun 1994 dengan Keputusan Presiden No. 36/1994 yang dilengkapi dengan penetapan Strategi Nasional Penanggulangan AIDS 1994. Kemudian, seiring meluasnya epidemi HIV dan AIDS sampai ke seluruh Indonesia menyebabkan munculnya upaya penanggulangan HIV dan AIDS melalui Perpres 75/2006 tentang Komisi Penanggulangan AIDS Nasional (KPAN)

14

http://www.aidsindonesia.or.id/contents/1/3/ yang secara formal bertugas untuk "meningkatkan upaya pencegahan dan penanggulangan AIDS yang lebih intensif, menyeluruh, terpadu dan terkoordinasi" serta langsung berada dibawah dan bertanggung jawab kepada Presiden. KPAN dalam Perpres 75/2006 melakukan penambahan anggota selain dari sektor pemerintah sipil dan militer, juga dari organisasi ODHA nasional, perwakilan dari komunitas LSM AIDS dan organisasi profesi serta swasta. Selain menunjukkan adanya peningkatan perhatian pemerintah terhadap bahaya HIV dan AIDS, KPAN ini juga menjanjikan kerjasama antar lembaga yang peduli terhadap persoalan ini.

Pada saat bersamaan banyak pihak yang peduli dan tergerak mendirikan yayasan atau lembaga. Dalam kerjanya ada spesifikasi pendekatan tertentu serta kelompok sasaran. Metode paling umum adalah lewat promosi kesehatan. Selain lembaga-lembaga yang terjun langsung mendampingi kelompok yang dianggap berisiko menularkan atau tertular HIV dan AIDS, ada juga kelompok-kelompok yang mendukung kegiatan ini melalui aktivitas penelitian dan advokasi kebijakan pada level pemerintah daerah (Wattie, 1998). Kebangkitan lembagalembaga ini, diikuti antusiasme pihak pendonor baik dalam maupun luar negeri yang berminat memberi dukungan finansial. Ini secara timbal balik menyebabkan semakin menjamurnya organisasi peduli HIV dan AIDS yang sudah mulai bermunculan sejak awal 1990-an.

Lembaga-lembaga yang muncul, mulai berperan dan mendapatkan donor dalam memerangi HIV dan AIDS, kemudian tidak selalu berbasis pada gerakan dengan isu kesehatan murni,

Sejarah\#sthash.nplcJdBn.dpuf, Diakses pada 14 September 2017, Pukul 5.54 WITA. 
tetapi juga mulai berbagai menyasar isuisu sosial budaya, terutama yang paling menonjol adalah lembaga-lembaga berbasis keagamaan atau Faith Based Organization (FBO). Kemudian, peran serta organisasi, tokoh serta masyarakatnya dalam usaha ini terindikasi dari salah satu pemberi dana terbesar untuk program penanggulangan HIV dan AIDS di Indonesia saat ini, yakni Global Fund for AIDS, Tubercolosis and Malaria (GFATM) yang sejak tahun 2011 mendanai organisasi berbasis agama Islam terbesar di Indonesia, Nahdlatul Ulama (NU). Selain NU, organisasi keagamaan Kristen, yaitu Persekutuan Gereja Indonesia dan Church World Service serta beberapa organisasi yang berafiliasi dengan agama lainnya juga terlibat pada program penanggulangan HIV dan AIDS.

GFATM lewat skema program Indonesian's Response to HIV memberi donor kepada Pengurus Besar Nadhlatul Ulama (PBNU) sebagai salah satu organisasi Muslim terbesar di Indonesia bersama dengan Perkumpulan Keluarga Berencana Indonesia (PKBI), Komisi Penanggulangan AIDS Nasional (KPAN) dan juga Kementerian Kesehatan sebagai penerima utama (principal recipient) untuk pendanaan periode 2010-2015 dengan besaran mencapai 2.000.000 USD.

NU membawahi tiga subrecipient (SR) yakni Yayasan Spritia, Yayasan Pelita Ilmu dan Yayasan Kusuma Buana. Pada gilirannya, setiap SR ini akan membawahi SSR (sub-sub recipient) lokal pada tiap wilayah kerja. Dalam masa kerjanya, NU dengan SR dan SSR-nya telah mengimplementasikan intervensi program HIV dan AIDS pada 21 provinsi. Salah satunya adalah dengan pembuatan pusat rehabilitasi narkoba. Selain itu, ada juga program pengintegrasian edukasi HIV dan AIDS di pesantren-pesantren. Seperti, pengguna Napza suntik dapat dirujuk ke pesantren-pesantren tertentu dengan tujuan memperoleh konseling religius. Ini menunjukkan kaitan NU sebagai organisasi berbasis agama dan kontribusinya terhadap promosi kesehatan berbasis komunitas, yakni program pencegahan HIV dan AIDS. Salah satu daerah yang menjadi sasaran program adalah Jawa Tengah.

Sementara itu, wilayah-wilayah dengan mayoritas penduduk nonMuslim dan bukan sasaran program NU, pembiayaan yang bersumber dari GFATM dikelola oleh PKBI, salah satunya di Bali. Sementara KPAD Bali dan Kota Denpasar serta lembaga atau yayasan yang bergerak dalam penanggulangan HIV dan AIDS juga memiliki sumber pembiayaan dari Anggaran Pendapatan dan Belanja Daerah (APBD) serta sumber-sumber lain. Sekalipun kadangkala tidak secara formal, implementasi program di Bali seringkali melewati dan memperoleh bantuan dari komunitas dan institusi keagamaan, seperti melalui tokoh PHDI (Parisada Hindu Dharma Indonesia) ataupun melalui pranata-pranata sosialkeagamaan lainnya, seperti Desa Adat. Lewat metode-metode seperti ini, institusi, tokoh, masyarakat dan nilai keagamaan yang ada secara langsung dapat terhubung dengan implementasi program penanganan HIV dan AIDS.

\section{Pengalaman FBO Dalam Penanganan HIV dan AIDS di Pantai Utara Jawa Tengah}

Sebagaimana telah dijelaskan, donor yang diperoleh oleh PBNU dilaksanakan untuk menangani HIV dan AIDS di 21 Provinsi. Ada pendekatan struktural berjenjang yang digunakan dalam mengoperasionalisasi program ini. Pelaksanaan program di tingkat provinsi diberikan wewenangnya kepada Pengurus Wilayah Nahdlatul Ulama (PWNU) yang diposisikan sebagai 
Sub-Recipient. Tiap provinsi mempunyai pendekatan dan cara kerja yang disesuaikan dengan potensi masing-masing, salah satunya Jawa Tengah wilayah dengan proporsi implementasi pendanaan terbesar yaitu mencakup 46\% dari jumlah program terkait yang diterima PBNU.

Di Jawa Tengah, SR atau SubRecipient ada pada PWNU Jateng. Kemudian turun ke SSR, yang meliputi: Fatayat (organisasi sayap NU bidang Perempuan Muda) tingkat Kabupaten/Kota, Muslimat (Organisasi Sayap bidang Perempuan), Kalandara, Spekham. Dalam beberapa kasus, pendekatan struktural yang hirarkis semacam ini tidak hanya menjangkau SSR tetapi juga dapat menyentuh hingga Implementing Unit (IU). Komposisi anggota inti dan pendukung SSR melalui pertimbangan-pertimbangan tertentu, dikombinasikan dengan mengambil unsur pekerja LSM internasional yang memiliki pengalaman dalam menangani isu ini dan ada dari internal organisasi NU. Masing-masing SSR terdiri dari tiga personil inti: Koordinator, bidang Monitoring dan Evaluasi (Monev) dan Keuangan (Finance). Meskipun Fatayat dan Muslimat adalah Banom (Badan Otonom) atau organisasi sayap NU, namun dalam praktek, penjangkau lapangan yang dipilih adalah yang sudah memiliki pengetahuan dalam isu HIV \& AIDS, tentu dikombinasikan dengan kader-kader internal. Beberapa kader yang dianggap potensial diberi pelatihan khusus untuk menjadi penjangkau lapangan dengan maksud sebagai langkah internalisasi pengetahuan dan kelangsungan program bagi internal organisasi.

Strategi dimaksud, digunakan karena dalam masa-masa awal pelaksanaan program, PWNU Jateng sadar belum punya pengalaman dalam mengelola program HIV AIDS dan merasa kebingungan, apalagi setelah mengetahui menerima proporsi yang lebih besar dibandingkan PWNU lain. NU memiliki LK (Lembaga Kesehatan), namun baru berdiri selama lima tahun, sehingga ada kesadaran bahwa mereka kurang berpengalaman dalam program ini, karena sekalipun memiliki banyak dokter, namun tidak secara serta-merta dapat dimobilisasi untuk bekerja dalam program ini. Namun begitu, ini juga dianggap sebagai momentum, karena:

"jika selama ini NU hanya mengurusi tahlilan, doa, pengajian dan sebagainya, itu tidak ada efek langsung dalam kemanusiaan, kepada mereka yang hidup. Kalau tahlilan kan ngurusin yang mati. Nah, ini momentum untuk itu" (Wawancara, Teddi, koordinator SRPWNU, 4 April 2015)

Kesadaran bahwa tidak mungkin mengimplementasi program dengan hanya bergantung pada sumberdaya internal, membuat PWNU Jateng merangkul pihak-pihak yang punya pengalaman. Sehingga, muncullah keputusan bahwa tim inti dikombinasikan dari kader NU dengan mereka yang memiliki pengalaman dan reputasi kerja dalam program penanggulangan HIV dan AIDS di Jawa Tengah yang umumnya berasal dari berbagai lembaga. Kolaborasi ini dianggap dibutuhkan agar mampu menutup kekurangan masing-masing. Kader NU diharapkan menjadi jembatan antara program dengan pengurus. Sementara, aktivis dari luar yang telah terbiasa mengerjakan program bisa menjaga alur program agar tetap pada koridor implementasi penanggulangan yang efektif.

Dalam awal masa kerja NU menangani program ini, pada tahun 2012 Kota Pekalongan mendapatkan MDG's award 2012 karena keberhasilan mereka mengurangi angka penularan HIV dan AIDS pada tahun sebelumnya. Ada asumsi awal bahwa penurunan 
angka ini karena Pekalongan dikenal sebagai kota santri dan juga merupakan wilayah kerja NU. Ini muncul dengan anggapan bahwa institusi keagamaan berperan penting dalam membentuk opini mengenai HIV dan AIDS, sehingga terjadi penurunan angka dimaksud. Namun begitu, kota ini bukan wilayah kerja PWNU dan PKBI Jawa Tengah. Karena, jika satu kota/kabupaten bukan wilayah kerja PWNU, maka itu akan merupakan wilayah kerja PKBI karena pada dasarnya PWNU yang merupakan Main Recipient Global Fund mengerjakan wilayah yang belum "disentuh" program PKBI. Anggapan paling masuk akal dalam penurunan angka ini adalah karena kasus HIV dan AIDS di Pekalongan termasuk kecil, sehingga penurunan angka mengakibatkan penurunan persentase terhitung yang signifikan. Alasan kecilnya angka HIV dan AIDS tersebut, sangat mungkin merupakan sebab dari tidak dimasukkannya Pekalongan dalam wilayah kerja kedua Main Recipient GF tersebut, yaitu PWNU dan PKBI Jateng.

Jika melihat kebelakang, keterlibatan organisasi berbasis agama sebesar NU secara formal dalam penanggulangan HIV dan AIDS belum pernah terjadi di Indonesia, apalagi di daerah Jawa Tengah. Hal ini dapat mengindiksikan pergeseran cara pandang pemuka agama terhadap HIV dan AIDS. Keterlibatan NU dalam program HIV dan AIDS di Indonesia diapresiasi positif oleh aktivis bidang ini. NU berperan penting terutama dalam internalisasi edukasi pada kader-kader mereka, sehingga dalam tingkat lokal, telah ada kelompok terlatih dalam isu HIV dan AIDS. Dengan demikian, ketika ada permasalahan, misalnya dalam urusan pemandian dan penguburan jenazah, anggota LSM atau Kelompok Dampingan Sebaya (KDS) dapat bekerja sama dengan kader-kader NU untuk mengurangi terjadinya diskriminasi di lapangan (Wawancara, Anonim, Yayasan Peduli Kasih Semarang, Juli 2014). Meski begitu, timbul pula rasa khawatir jika nantinya setelah selesai dilatih dan kembali ke daerahnya masing-masing, kader-kader ini akan kehilangan minat baik karena kekurangaktifan mereka sendiri atau karena kurangnya dana operasional.

Pola hubungan patronistik yang terjadi di kalangan NU, terutama antara pemuka agama dan santri-santri serta warga pada umumnya dianggap sebagai pintu masuk untuk membangun diskursus yang lebih seimbang dan nondiskriminatif di kalangan masyarakat. Pengetahuan tokoh agama mengenai HIV dan AIDS dibangun dari beragam pelatihan dan penerbitan buku panduan, misalnya buku AIDS dalam Perspektif NU. Pada level praktek, terselenggara kegiatan pendampingan terhadap ODHA dengan melibatkan tokoh agama pada kegiatan yang langsung bersentuhan dengan kasus-kasus HIV dan AIDS misalnya dalam bentuk kunjungan pasien.

Dalam kasus pengembangan diskursus untuk mengenai HIV dan AIDS, NU juga mengadakan sebuah sidang yang diikuti para kyai, untuk membahas Fiqh (tafsiran dan pandangan) terkait HIV dan AIDS. Hasilnya adalah buku Panduan Penanggulangan AIDS Perspektif Nahdlatul Ulama. Hal tersebut juga diikuti seorang kader NU dari Kebumen yang menulis sebuah buku semi novel edukatif berjudul "Surga Untuk ODHA". Hal-hal tersebut, jelas merupakan bagian dari strategi PWNU Jateng adalah mengkombinasikan kekuatan pengaruh tokoh agama dalam sosialisasi mengenai HIV dan AIDS di kalangan masyarakat umum.

\begin{tabular}{lcr}
\multicolumn{1}{c}{ Selain dapat dilihat } & sebagai \\
sinyalemen & positif & dalam \\
penanggulangan HIV dan & AIDS, \\
keterlibatan FBO Muslim dalam hal ini
\end{tabular}


mayoritasnya diperankan oleh NU yang pengaruhnya sangat kuat dalam wilayah-wilayah santri seperti daerah Pantura, seringkali juga bisa berarti paradoksal. Pada sisi lain, diskursus keagamaan yang seringkali meruncingkan diskriminasi, justru direproduksi karena pandanganpadangan sosio-kultural yang diperoleh dan disebarkan lewat tokoh-tokoh dan mereka yang terlibat dalam FBO. Cerita mengenai diskriminasi berasal dari pemuka agama merupakan hal yang umum didengar dan merembes dalam kehidupan keluarga, lingkungan tempat tinggal dan bekerja. Hal ini nampak dari aktivis FBO yang juga merupakan seorang ODHA, yaitu:

"saya belum pernah mengalami perlakuan diskriminasi, ataupun stigma, sehingga kurang bisa merasakan. Tetapi banyak diceritakan oleh teman-temen di lapangan. Misalnya seorang ibu rumah tangga yang sudah positif. Terus diketahui, entah bagaimana caranya, beredar info kalau dia terinfeksi HIV dan biasanya kebocoran status itu dari oknum institusi kesehatan malahan di rumah sakit atau puskesmas yang memberitahukan ke masyarakat dimana ia biasa tinggal. Ibu tersebut kebetulan aktif kegiatan pengajian, secara serta merta ketika dia diketahui terjangkit, dia tidak diundang lagi ke pengajian lagi oleh masyarakat sekitar (Wawancara, Anonim, Juli 2014)"

Informan ini merupakan tokoh dalam KDS yang kini aktif dengan LSM berbasis komunitas ODHA dengan beberapa rekannya di Semarang yang terhubung dengan program dari PWNU, dimana lembaganya menjadi Sub-Sub Recipient (SSR) dari kerjasama GF dan NU di bawah Yayasan Spirita Jakarta untuk pendampingan ODHA. Ia juga melanjutkan ada banyak pengalaman terdahulu yang memperlihatkan bagaimana jenazah ODHA kerap didiskriminasi yang diinisiasi oleh tokoh agama, bahkan untuk urusan-urusan yang terkait ritual keagamaan seperti pemandian jenazah dan acara doa tahlilan. Meskipun secara pribadi, sebagai ODHA ia belum pernah merasa didiskriminasi oleh tokoh agama, namun ini dimungkinkan karena ia sangat berhati-hati dan rahasia dalam menjaga serta membagikan statusnya sebagai ODHA. Pengalamannya sebagai pendamping sesama ODHA menunjukkan bahwa diskriminasi dan stigma justru direproduksi, salah satunya oleh tokoh umat beragama baik di tingkat lokal dan kemudian secara luas disebarkan warga beragama lewat pertemuan-pertemuan, seperti pengajian, arisan ataupun dalam khotbah-khotbah.

Sebelum keterlibatan FBO atau dalam hal ini NU secara formal, pada dasarnya hubungan dengan komunitas LSM yang bergerak dalam bidang penanggulangan HIV dan AIDS telah terbentuk lebih awal, kemudian berlanjut ketika FBO dalam hal ini NU secara formal telah terlibat dalam usahausaha ini. Berbagai kelompok yang bekerja dalam bidang ini telah berperan banyak dalam edukasi kepada para tokoh agama, setidaknya pada level lokal. Sementara, program sejenis yang diinisiasi negara atau pemerintah seringkali belum menyentuh aspek ini. Padahal, tokoh agama lewat pengalaman empirik sering didengar sebagai referensi utama dan penting dalam melaksankan perlakuan tertentu terhadap ODHA atau jenazahnya, sebagaimana terlihat dalam pendapat dari informan yang merupakan pengelola program penanggulangan HIV/AIDS dari FBO di daerah Pantura:

"Pernah ada kejadian orang AIDS meninggal dan tokoh agama yang biasanya mencuci jenazah justru 
tidak mau melakukannya. Kemudian, dia justru bilang kepada keluarga agar jenazah jangan dipegang nanti menular. Padahal karena kedekatan keluarga, apapun namanya, keluarga kan biasanya tidak terpengaruh. Tapi, karena tokoh bilang begitu, keluarga akhirnya mengikuti. Ini berarti tokoh agama di tingkatan lokal ternyata didengar oleh masyarakat. Akhirnya, Kelompok Dukungan Sebaya yang ada waktu itu melakukan pendekatan dan advokasi, bahkan membawa lurah bicara kepada tokoh agama bersangkutan sekaligus dilakukan edukasi, pendekatan serta pendampingan beberapa kali. Akhirnya, tokoh agama bersangkutan, sekarang keliling dan memberikan informasi mengenai bahwa jenazah ODHA tidak masalah dimandikan dengan teknik tertentu untuk mengurangi ketakutan. Ini dilakukan dari mulut ke mulut. Jadi, jika sekarang menunggu program nasional atau pemerintah misalnya, itu akan sulit untuk bisa sampai ke grassroot. Tapi kalau kita potong kompas itu bisa dilakukan sedini mungkin, sekalipun ada kesan terlambat, karena memang kebanyakan muncul kasus duluan. Memang kita seperti pemadam kebakaran istilahnya, ada kasus baru datang, walaupun kami ingin lingkungan menjadi lebih kondusif dan juga nyaman untuk ODHA, tapi ke arah sana masih dibutuhkan perjuangan panjang" (Wawancara, Anonim, Juli 2014)

Dalam wilayah Pantura, tokoh agama yang dirangkul oleh FBO dalam usaha membangun suatu lingkungan yang lebih sadar akan bahaya HIV dan AIDS serta lebih ramah kepada ODHA, juga kadangkala muncul seperti pedang bermata dua. Ada peluang bagi mereka untuk teredukasi lebih baik, sehingga secara strategis berperan penting dalam mengurangi diskriminasi dan menyebarluaskan informasi yang tepat tentang HIV dan AIDS. Namun juga, tak hilang kesempatan bagi para tokoh ini untuk ikut meruncingkan diskriminasi secara lebih luas ke masyarakat.

Hal di atas nampak seperti pengalaman ketika diadakan program edukasi dalam bentuk diskusi, beberapa tokoh pesantren diundang. Tetapi, pembicara yang diundang oleh PWNU sebagai aktifis HIV dan AIDS serta memberi testimoni selaku ODHA kemudian disudutkan. Tokoh pesantren yang selanjutnya bicara, mengawali perbincanganya dengan: "jadi, yang anda alami adalah bagian dari penebusan dosa, itu harus diterima", dimana sang tokoh tidak menggunakan bahasa yang merangkul tetapi menyudutkan (Wawancara, Anonim, Juli 2014). Dalam hal ini, pendekatan yang dilakukan FBO untuk merangkul tokohtokoh agama jelas penting karena mereka punya kekuatan sosial yang potensial untuk didengar warga, tetapi juga seringkali memberi permasalahan dalam menghadapi opini yang diskriminatif para tokoh agama sendiri yang secara potensial bisa meluas di tengah masyarakat.

\section{Civil Society dan Pengalaman FBO Dalam Penanganan HIV dan AIDS di Bali}

HIV dan AIDS di Bali mulai berkembang setidaknya tahun 1997 dimulai saat seorang wisatawan asal asal Eropa yang diduga menjadi pembawa virus pertama. Sejak saat itu, lembaga civil society yang mengkhususkan diri untuk mengelola isu ini mulai bermunculan, antara lain Yayasan Citra Usada Indonesia (YCUI), Yayasan Kerti Praja (YKP), Yayasan Dua Hati (YDH), Yayasan Spirit Paramachita (YSP). Lembaga-lembaga tersebut memulai programnya dengan dana 
swadaya ataupun donor dari dalam maupun luar negeri. Kerjasama antar lembaga yang bergerak di bidang ini terus berkembang serta menjadi lebih terfasilitasi sejak tahun 2006 ketika KPAD Provinsi Bali terbentuk dan menjalankan fungsi koordinasinya.

Tiap lembaga memiliki segmentasi tersendiri dalam menjalankan program, ada yang fokus kepada para Pekerja Seks, kalangan LGBTQ, Remaja, Pemakai Jarum Suntik dan masyarakat umum. Perbedaan fokus secara tidak langsung membantu KPAD Bali dalam menjalankan fungsi koordinasi dan memantau jumlah kasus di tiap kelompok yang dianggap berperilaku berisiko.

Hal menarik bahwa lembaga dan yayasan yang menangani kasus HIV dan AIDS di Bali tidak secara tegas dan bahkan menolak menyebutkan afiliasi organisasi dengan agama mayoritas, yaitu Hindu Bali. Lembaga-lembaga ini cenderung bersifat sekuler dan inklusif, seluruh program kegiatan diselenggarakan dalam kerangka medis atau kesehatan. Pihak YKP menjelaskan bahwa tidak strategis menggunakan pendekatan agama Hindu dalam mengelola isu ini di Bali, karena 90\% Pekerja Seks berasal dari luar Bali (Wawancara, Anonim, Juli 2014). YCUI juga menganggap pendekatan agama dikhawatirkan membuat masyarakat tidak mendapat informasi lengkap tentang HIV dan AIDS serta bagaimana cara menanggulanginya (Wawancara, Anonim, April 2015).

Namun demikian, kerjasama dengan kelompok-kelompok keagamaan yang terafiliasi dengan komunitas adat pasti terjadi dalam beberapa kesempatan. Ada kebutuhan bahwa dalam kegiatan tertentu, tokoh agama Hindu perlu terlibat. Terutama untuk

${ }^{15}$ Clifford Geertz, "Form and Variation in Balinese Village Structure", (Journal American Anthropologist, Vol. 61, 1959), h. 991-1021. menyampaikan pesan-pesan moral yang terkandung di dalam sloka-sloka di kitab suci yang berguna bagi kesehatan dan kehidupan manusia yang terkait dengan penanganan HIV dan AIDS. Dari sini, karena pertimbangan-pertimbangan tertentu dapat terlihat bahwa hubungan yang terjalin dengan FBO atau oknum di dalamnya terjadi secara tidak langsung.

Sekalipun FBO diikutsertakan secara non-organisasional, bukan berarti pranata keagamaan dalam mengelola isu HIV dan AIDS di Bali memiliki nilai yang lemah. Tetapi, justru ini karena tidak mungkin melepaskan nilai Hindu-Bali dalam penanganan isu HIV dan AIDS dalam konteks lokal. Hindu dan Bali merupakan dua entitas identitas dan sistem nilai sebagai kesatuan yang tidak bisa dipisahkan, tentu dalam arti sistem kepercayaan dan adat istiadat yang mengikat komunitas ini dalam berbagai aspek hidup. Prakteknya, pengaturan kehidupan religi dan adat dibasiskan pada setiap desa adat atau Banjar.

Banjar mengatur regulasi lokal atau awig-awig yang berkaitan dengan adat, dalam kepercayaan ini siapa saja yang berani melanggar atau mencederai peraturan dan mengganggu hubungan religius yang harmonis dengan para leluhur serta dewa-dewa akan tertimpa wabah penyakit dan konflik, sehingga dipercaya mengatur relasi antara kehidupan leluhur yang masih hidup dan leluhur telah tiada. ${ }^{15}$ Keterikatan yang begitu besar dengan adat, membuat pihak-pihak yang terlibat dalam masalah HIV/AIDS di Bali mengembangkan setidaknya dua program utama melibatkan Banjar, yang dapat dianggap sebagai FBO yang mengatur satuan komunitas teritorial berdasarkan nilai religius Hindu-Bali. Program tersebut adalah pembentukan 
Kader Desa Peduli AIDS dan Narkoba (KDPAN) dan Kader Sekolah Peduli AIDS dan Narkoba (KSPAN) yang bertujuan mendampingi masyarakat dan ODHA serta membantu berbagai program pemerintah terkait HIV dan AIDS. Program ini dibentuk tahun 2011 lewat ide yang diinisiasi YCUI. Sumber pendanaan melalui pemerintah Provinsi dan teknisnya dilaksanakan, oleh: 1) KPAD Provinsi Bali; 2) Dinas Kesehatan; 3) Dinas Pariwisata; 4) Dinas Pendidikan; dan 5) Kanwil Kementerian Agama Provinsi Bali.

KDPAN dibentuk di setiap Banjar di Bali, tiap desa adat memiliki lima belas orang. Kader diberi pelatihan mulai dari bagaimana mendata warga yang terkena HIV dan AIDS, merujuknya ke PUSKESMAS atau Rumah Sakit terdekat, memberi informasi tentang penyakit ini pada warga desa dan teknik bagaimana memandikan jenazah ODHA. Informasi yang diberikan diharapkan diaplikasikan dalam desa adat ketika menemui kasus di lapangan. Pendekatan program ini, terutama dari aspek medis, namun dalam kasus upacara Kematian, dilakukan pendekatan dan kerjasama khusus dalam sosialisasi dan edukasi dengan Pemangku agama di Banjar setempat.

Kematian bagi ODHA dengan latar belakang Hindu-Bali memiliki posisi penting dalam sistem nilai lokal, selain kelahiran dan pernikahan. Kematian menjadi tolak-ukur dan simbol bagaimana kehidupan seseorang selama di dunia, hal mana dapat terlihat dari ritual kematian Hindu Bali. Kematian dipercaya sebagai bagian dari siklus hidup warga Hindu-Bali dan ada dua cara kematian yang tidak normal yaitu yang sengaja mencari mati dengan cara perbuatan bunuh diri (ulah pati) dan seseorang yang yang meninggal

16 Warren, Carol, Indonesia Development Policy and Community Organization in Bali, tidak mengikuti ketentuan aatau menyimpang dari proses alami (salah pati) contohnya akibat kecelakaan. Dalam banyak kasus warga lokal, mengidap HIV dan AIDS seringkali dianggap berpotensi meninggal dalam cara tidak normal atau salah pati.

Hal mengenai Kematian ini menjadi sangat terkait dengan proses edukasi, penerimaan bahkan diskriminasi ODHA di tengah-tengah masyarakat Hindu-Bali dan disinilah peran Banjar sebagai FBO menjadi sangat strategis dalam membentuk diskursus mengenai HIV dan AIDS dalam tataran lokal, walaupun mereka terlibat secara tidak langsung. Bagi warga lokal, tidak diterimanya seseorang saat meninggal dunia, menjadi momok menakutkan terutama bagi yang tinggal di luar desa adatnya, entah hanya berbeda kota maupun sampai ke luar pulau. Hal ini sering menghantui warga dengan penyakit tertentu yang sengaja pergi dari rumah demi menutupi sakitnya dari orang-orang terdekat. Alam kematian sangat terkait dengan Banjar, bagi orang Bali, jika seseorang meninggal dunia ia akan ditanyai oleh Tuhan, "apakah kamu diantarkan oleh warga Banjarmu saat kamu mati?", jika jawabannya tidak, maka ia akan dikembalikan ke bumi. ${ }^{16}$ Ketakutan seperti ini dirasakan ODHA di Bali, karena sebagian besar mereka terinfeksi saat sedang merantau ke luar daerah dan dengan begitu mereka tidak terlibat langsung dengan kehidupan Banjar asalnya.

Kekhawatiran seperti ini seringkali muncul pada ODHA dimana mereka cenderung kembali ke Banjar mereka jika telah mengetahui positif terjangkit. Dalam beberapa kesaksian yang diperoleh dari ODHA, warga Banjar pada awalnya sulit menerima ODHA.

(Contemporary Southeast Asia, Vol. 8, No. 3, 1993), h. 213-230. 
Dalam kasus semacam ini, pemangku adat di Banjar masing-masing ataupun Pandita seringkali dihubungi untuk menjalin komunikasi, misalnya dengan memberikan penjelasan dengan mengatakan bahwa setiap orang akan meninggal dengan jalan masing-masing, termasuk melalui HIV dan AIDS (Wawancara, Anonim, Juli 2014). Ada pula kasus meskipun kalangan pemangku sudah bisa menerima kondisi ODHA, namun masyarakat masih banyak yang belum menerima (Wawancara, Anonim, Juli 2014). Namun lewat proses komunikasi, saat ini kebanyakan masyarakat sudah terbiasa dalam menghadapi ODHA di Banjar masingmasing dan diskriminasi yang dirasakan semakin berkurang (Wawancara, Anonim, Juli 2014). Bagi informan, penerimaan masyarakat lebih bergantung pada perilaku ODHA terhadap kegiatan masyarakat adat terutama di Banjar masing-masing, semakin intensif partisipasi ODHA dalam kegiatan adat maka semakin mungkin mereka diterima masyarakat (Wawancara, Anonim, Juli 2014).

Persoalan yang kemudian timbul adalah ketika ODHA meninggal dan jenazahnya harus dimandikan yang seringkali warga dan pemangku adat serta agama enggan melakukannya. Ketika masalah ini terjadi, awalnya warga ODHA KDS Kasih Karunia sering sekali dimintai bantuan karena masyarakat masih enggan memandikan jenazah dengan HIV dan AIDS. Dalam momen-momen semacam inilah, KDS ODHA, lembaga yang bergerak di bidang ini dan KDPAN mengambil peran

17 Dalam kasus ODHA jenazah harus didiamkan selama empat jam sebelum dimandikan. Hal ini dilakukan untuk memastikan bahwa virus-virus yang ada dalam tubuh jenazah mati terlebih dahulu. Orang yang memandikan harus menggunakan sarung tangan, dan tidak boleh memiliki luka di seluruh tubuhnya. Bahan yang digunakan untuk memandikan jenazah adalah air yang dicampur sosialisasi memandikan jenazah dengan aman sekaligus memberi contoh pada masyarakat, misalnya dengan menaruh jenazah di balai duka dengan alas plastik dan mempraktekan bagaimana cara memandikannya. Dengan begitu, masyarakat bisa melihat langsung proses pemandian tersebut.

Upacara memandikan jenazah adalah salah satu bagian dari upacara Pitra Yadnya yang penting bagi masyarakat Hindu-Bali. Upacara ini lebih banyak meritualkan pemeliharaan badan secara baik karena diharapkan mereka meninggal setelah dimandikan akan menghadap Tuhan dengan bersih dan dapat bereinkarnasi lebih sempurna dari sebelumnya. Bagi ODHA, tanpa mengurangi esensi ritual, pemangku adat sebagai orang yang akan memandikan jenazah dan pemimpin ritual diberi tambahan edukasi dan pelatihan mengenai teknik pemandian Jenazah ${ }^{17}$. Sekaligus mereka juga diharapkan dapat meyakinkan warga mengenai keamanan berinteraksi dengan ODHA dan memandikan jenazah mereka.

Proses memandikan jenazah merupakan hal paling sulit dalam pelatihan KDPAN, terutama bukan karena hal teknis namun membangun keyakinan kader dan warga bahwa mereka tidak akan tertular hanya karena memandikan jenazah ODHA. Sebelum KDPAN dibentuk, KPAD provinsi Bali telah membuat buku berjudul 'Tata Cara Nyiramang Layon" atau Tata Cara Memandikan Jenazah, khususnya jenazah yang semasa hidup terinfeksi HIV/AIDS. Dimana, karena terkait

dengan larutan natrium hipoklorida (zat pemutih pakaian) dengan perbandingan 1:10. Jika terdapat luka pada tubuh jenazah, bagian luka ditutup dengan plester kedap air. Setiap lubang tubuh ditutup dengan kapas yang telah dibasahi dengan natrium hipoklorida dan jenazah harus diawetkan dengan formalin berkadar $4 \%$. 
dengan aspek ritual Hindu-Bali, buku ini disusun dengan bantuan pemangku agama. Respons terhadap buku ini ternyata cukup baik, terutama untuk internalisasi menurunkan rasa takut dalam memandikan jenazah ODHA, hal mana membuat KPAD Bali mengeluarkan buku ini secara reguler untuk dibagikan seluas mungkin kepada warga, terutama lewat lembagalembaga yang menangani isu HIV dan AIDS, pemangku agama dan pemangku adat di tiap Banjar, KDPAN serta KSPAN. Proses-proses

kerjasama program antara pemerintah, civil society lewat lembaga dalam bidang HIV/AIDS, serta pemangku adat dan agama di tiap desa adat, telah semakin membentuk kesadaran dan diskursus berimbang, bahwa harus hati-hati terhadap penyakit ini tetapi tidak perlu mendiskriminasi dan bergaul menjauhi ODHA. Mayoritas informan ODHA menyatakan bahwa saat ini mereka lebih nyaman di masyarakat karena telah dianggap sebagai sosok yang tak perlu lagi harus dihindari. Mereka lebih memiliki kepercayaan diri untuk tampil di depan publik untuk kepentingan positif, memberi memotivasi sesama ODHA sekaligus sebagai contoh tentang ODHA yang tetap bisa melanjutkan hidup dan melakukan kegiatan-kegiatan produktif.

\section{Kesimpulan}

Artikel ini menjelaskan bahwa, pada dasarnya dalam masing-masing wilayah telah ada perubahan persepsi terhadap kasus HIV dan AIDS dari kalangan masyarakat beragama dalam memberi respons terhadap HIV dan AIDS baik secara kelembagaan maupun individual, entah itu khalayak umum atau para pemuka agama.

Daerah Pantai Utara Jawa Tengah, lewat mekanisme introduksi pendanaan internasional, secara kelembagaan telah mulai menerima diri untuk menerima isu HIV dan AIDS sebagai salah satu pokok perhatian kerja pembentukan wacana dan praktek nondiskriminatif serta pendampingan kepada ODHA. Dimana ini merupakan pemberian perhatian, pengelolaan dan penerimaan program pertama secara langsung FBO berbasis Islam sebesar NU terhadap isu HIV dan AIDS, dalam hal ini PBNU dan lebih khusus PWNU Jawa Tengah. Dari sini dapat disimpulkan bahwa program kerja dan jejaring lembaga di Pantura berjalan karena ikatan pada sumber dana yang sama dan lewat pendekatan struktural atau organisasional.

Lewat program-program yang dilaksanakan, memang telah ada proses penerimaan non diskriminatif dari warga, termasuk para pemuka dan penggiat agama yang umumnya masih relatif muda, yaitu antara 20an sampai 40an tahun. Namun, perkembangan ini tidak dapat dianggap terlalu menggembirakan atau cukup signifikan, karena nyatanya masih terlalu umum ditemukan warga dan pemuka agama yang melakukan praktek diskriminasi dan menyudutkan ODHA dalam artian wacana dan praktek sosial. Hal ini juga memperlihatkan, bahwa proses penerimaan masyarakat dan pemuka agama terhadap isu HIV dan AIDS di daerah Pantura Jawa Tengah cenderung lebih kaku dan sulit. Namun, mempertimbangkan bahwa program kesigapan terhadap isu HIV dan AIDS oleh FBO yang sangat berpengaruh seperti NU baru dimulai sekitar lima tahun, maka bisa dianggap bahwa wacana dan praktek sosial yang terbentuk sejauh ini masih merupakan sebuah rintisan.

Sebaliknya, kasus Bali menunjukkan bahwa FBO berbasis komunitas teritorial yang terutama dalam bentuk Banjar atau desa adat diikutsertakan secara tidak langsung dan tidak terafiliasi secara formal 
dengan lembaga yang bekerja di bidang HIV dan AIDS baik LSM maupun pemerintah khususnya KPAD. Dalam kata lain, FBO diikutsertakan sebagai pendukung pada kegiatan-kegiatan spesifik, seperti tata cara memandikan jenazah. Selain itu, kegiatan implementasi program justru bergerak dengan sumber dana beragam, dimana lembaga peduli HIV dan AIDS di Bali mampu beroperasi cukup sinergis, termasuk bekerjasama dengan seluas mungkin lapisan masyarakat hingga ke tingkat desa adat atau Banjar.

Pada posisi ini, disimpulkan bahwa pemahaman serta praktek sosial masyarakat terhadap kasus HIV dan AIDS sudah berjalan baik dalam skema kerjasama yang cukup matang, walau bersifat tentatif sesuai program. Salah satunya karena peran lembaga keagamaan PHDI (Parisada Hindu Dharma Indonesia) Bali dalam program terkait HIV dan AIDS yaitu melalui kerjasama penerbitan buku pemulasaraan jenazah yang sejauh ini cukup efektif membangun praktek nondiskriminatif terhadap ODHA. Termasuk secara struktural dalam mempengaruhi praktek penerimaan pemuka agama kepada ODHA hingga ke tingkat Banjar.

Dapat dikatakan, secara sosiokultural dan kelembagaan hingga tingkatan akar rumput, masyarakat Bali cukup mudah, luwes dan terbuka menerima program dan memperbaharui wacana mengenai HIV dan AIDS, termasuk berlaku secara sosial terhadap ODHA. Kondisi mana memperlihatkan bahwa pada dasarnya warga telah cukup terinternalisasi dengan pengetahuan memadai mengenai HIV dan AIDS, sehingga halangan-halangan sosial dan kultural dalam berlaku diskriminatif pada ODHA relatif lebih mudah direduksi. Hal ini juga bisa dimungkinkan, karena secara sosiokultural, ODHA dapat membangun komunikasi secara lebih terbuka dengan pemangku adat dan agama serta masyarakat setempat soal kondisi mereka. Apalagi, komunikasi dapat dibangun secara simbolis melalui keikutsertaan secara intensif pada kegiatan adat dan keagamaan di Banjar masing-masing yang mempermudah penerimaan sosial. Tetapi bisa pula digarisbawahi, bahwa program penanganan HIV dan AIDS di Bali yang berjejaring dengan lembaga keagamaan pada dasarnya telah berjalan kurang lebih dua dekade, sehingga dalam hal skema, perencanaan dan jejaring lembaga sudah relatif terbentuk lebih matang. Apalagi, didukung oleh faktor kondisi dimana masyarakat lebih adaptif dalam menerima isu HIV dan AIDS.

Secara komparatif, ada beberapa perbedaan mendasar dalam mengelola isu HIV dan AIDS oleh FBO di daerah Pantura Jawa Tengah dan Bali, baik secara internal dan eksternal. FBO di Jawa tengah terlibat dan mengelola secara langsung dimana ini terjadi karena pendekatan yang dilakukan adalah secara struktural dan organisasional, salah satunya karena terikat pada sumber pendanaan yang sama, sekalipun tetap juga mencoba membangun jejaring dengan pihak lain, namun itu dilakukan dengan mengikutsertakan pihak luar ke dalam struktur pengelolaan program. Ini terlihat, selain dari program yang dilaksanakan yang pada umumnya melibatkan santri, kader dan jejaring organisasional, tetapi juga SSR dan IU yang mengimplementasikan program merupakan sayap organisasi ataupun lembaga, seperti Fatayat dan Muslimat. Sementara di Bali, pelibatan FBO terjadi secara tidak langsung dan programnya cenderung lewat jejaring berbasis informal yang diambil dari sumbersumber eksternal pengelola. Hal ini terjadi, selain karena telah dahulu melaksanakan program HIV dan AIDS, tetapi juga karena di Bali memiliki 
segmentasi sasaran program yang lebih spesifik dan berbeda, tetapi juga sumber pendanaan mereka lebih variatif dan tidak hanya bersumber dari donor tunggal, dimana pemerintah juga memainkan peran koordinasi lewat KPAD Bali.

Dalam hal penerimaan program, latar belakang kondisi masyarakat dengan agama dominan yang diyakini masing-masing serta peran para pemukanya juga telah berpengaruh dalam menginternalisasi wacana serta membangun respons sosial mengenai HIV dan AIDS serta terhadap ODHA. Pantura Jawa Tengah cenderung lebih religius dalam hal pendekatan dan segmentasi program, dimana warga dan para pemuka agama cenderung lebih kaku menerima wacana program, kecuali kelompok-kelompok pemuka dan penggiat keagamaan yang lebih muda dan adaptif. Sementara di Bali, sekalipun tidak mengenyampingkan aspek keagamaan, pendekatan dilakukan cenderung lebih sekuler, egaliter dan personal. Dimana, struktur masyarakat secara luas dan mendalam lebih mudah menerima wacana HIV dan AIDS serta berpraktek atas hal tersebut. Hal mana dimungkinkan karena pada dasarnya, program penanganan HIV dan AIDS ini telah berlangsung lebih lama, yaitu kurang lebih dua dekade.

\section{DAFTAR PUSTAKA}

Crisovan, P., 'Risky' Business: Cultural Conception of HIV/AIDS in Indonesia. Ph.D Dissertation. Graduate Faculty of the Department of Anthropology, School of Arts and Sciences, University of Pittsburgh, 2006.

Cheema, Bani, Combating HIV/AIDS in Marginalized Communities: Papua and West Papua Provincies, Master Thesis, University of San Fransisco, 2014.

Ford, K., Voluntary, HIV testing, disclosure among injections drug users in Bali, Indonesia, AIDS; Education and Prevention, 2014.

Geertz, Clifford (1959) "Form and Variation in Balinese Village Structure", Journal American Anthropologist, No. 61, 1959.

Hyder, Adnan Ali and Richard Morrow, "Culture, Behavior and Health", in Michael Merson, et. al. (Eds.), International Public Health: Diseases, Programs, Systems and Policies, Sudbury: Jones and Bartlet Publishers, 2006.

Ibrahim, K., Songwathana, P., and Boonyasopun, $\mathrm{U}$, The HIV/AIDS epidemic in Indonesia: Does primary health care as a prevention and intervention strategy work? " International Journal of Nursing Practice, 2010.

Kelly, A., The Body of Christ has AIDS: The Catholic Church Responding Faithfully to HIV and AIDS in Papua New Guinea, Journal of Religion and Health, No. 48, 2009.

Kroeger, K. A., Risk, Boundary Making and the Social Order: Understanding the social construction of AIDS and sexuality in Indonesia. Ph.D dissertation. Washington: Graduate School of 
Arts and Sciences of Washington University. 2000.

Madyan, Ahmad Syams, The Reproduction of Discourse, The Exercise of Power and Creation of Piety In The Issue of HIV an AIDS and Islam in Indonesia", Journal Religio: Jurnal Studi Agamaagama, Vol. 3, No. 2, September 2013.

Monshipouri, Mahmood and Travis Trapp, HIV/AIDS, Religion, and Human Rights: A Comparative Analysis of Bangladesh, Indonesia, and Iran, Human Rights Review, No. 13, 2012.

Nasir, S. dan D. Rosenthal, The social context of initiation into injecting drugs in the slums of Makassar, Indonesia: International Journal of Drug Policy, No. 20, 2009.

Rhodes, Tim and Alan Quirk, "Heroin, Risk and Sexual Safety: Some problems for interventions encouraging community change". In Tim Rhodes and and Richard Hartnoll (eds). AIDS, drugs and prevention: perspectives on individual and community action London dan New York: Routledge, 1996.

Surur, Feirus dan Mirgissa Kaba, The Role of Religious Leaders in HIV/AIDS Prevention, Control, and Patient Care and Support: A Pilot Project in Jimma Zone, Journal Northeast African Studies, Vol. 7, No. 2, 2000.

Waluyo, Agung; Gabriel J. Culbert; RN Judith Levy; Kathleen F. Norr, Understanding HIV-Related Stigma Among Indonesian Nurses, Journal Of The Association of Nurses In Aids Care, 2014.

Warren, Carol, Indonesia Development Policy and Community Organization in Bali, Contemporary Southeast Asia, Vol. 8, No. 3, 1993.
Wattie, Anna Marie, "A Fresh Look At Sexuality and HIV/AIDS: Indonesian Experience" in a Fresh Look at Sexuality and HIV/AIDS in Asia and the Pacific, Proceedings of the Satellite Workshop on Sexuality, Task Force on Social Science and Reproductive Health Social Development Research Center College of Liberal Arts. De La Salle University, Philippines, 1998.

https://www.ugm.ac.id/berita/10789.a ngkainfeksi.baru.hivaids.di.indon esia.capai.25.ribu.per.tahun, diakses 31 Agustus, Pukul 1.28 WITA.

http://www.aidsindonesia.or.id/conten ts/1/3/Sejarah\#sthash.nplc]dBn. dpuf, Diakses pada 14 September 2017, Pukul 5.54 WITA. 
JURNAL AQLAM -- Journal of Islam and Plurality -- Volume 3, Nomor 1, Juni 2018 